mgr inz. Tomasz Gazdulski

dr hab. Jerzy Lewiński, prof. IPS

mgr inz. Mariusz Far

Instytut Pojazdów Szynowych „TABOR”

\title{
Possibility of optimizing the chassis of modern passenger wagons in relation to reduction of their weight
}

\section{Możliwość optymalizacji podwozi współczesnych wagonów osobowych w odniesieniu do redukcji masy}

\begin{abstract}
The requirements imposed on modernized and new rail vehicles are increasing. They are related to safety and environmental protection, and aimed at improving the travel operational parameters and comfort. Therefore, the weight reduction of rail vehicles plays an increasingly important role in the designing process. The paper presents the construction of the chassis of modern passenger coaches and specification of the masses of particular components of the coach chassis. The directions of development of the passenger coach chassis are proposed, with a view to reduce its weight.
\end{abstract}

Wymagania stawiane zarówno modernizowanym jak i nowym pojazdom szynowym sq coraz większe. Dotycza one bezpieczeństwa i ochrony środowiska, a z drugiej strony polepszenia parametrów eksploatacyjnych oraz komfortu podróżowania. Redukcja masy pojazdów szynowych odgrywa coraz większa role podczas procesu konstruowania. Wartykule przedstawiono konstrukcje podwozi wspótczesnych wagonów osobowych, dokonano analizy mas poszczególnych elementów podwozia wagonowego oraz zaproponowano kierunki rozwoju budowy konstrukcji podwozi wagonów osobowych w odniesieniu do redukcji masy.

\section{Introduction}

Nowadays, the trends to save energy, to protect the environment and to increase the rail vehicle capacity and payload are conducive to reduction of its weight. Mass reduction of the bogies, body (side and front walls, with roof included) and the chassis (the framework with the floor) contributes to weight reduction of the entire vehicle. The mass can be reduced by changing the cross-sections of the main structural elements, the use of innovative construction materials or combination of both these approaches $[1$, 6].

Yao et alii [10] made attempts to apply a lightweight composite to build the bogie frame elements, reducing the weight of these parts by about $30 \%$ as compared to the ones made of traditional materials.

Kang SeungGu et alii [4] proposed optimization of the topology of the high-speed double-decker coach and pointed the parts that can be replaced with the elements made of multilayer composites. It was shown that weight of the body made of aluminum and composite elements may be even $14 \%$ lower as compared to a traditional aluminum construction. A similar result, of about $14 \%$ mass reduction, was achieved by Jeong Gil Cho et alii [2] in the course of K-EMU body optimization, in result of replacing

\section{Wstęp}

Obecnie oszczędność energii, ochrona środowiska, jak i chęć zwiększania pojemności oraz ładowności wymuszaja redukcje masy pojazdów szynowych. Obniżenie masy takich elementów jak wózki, nadwozie (ściany boczne, czołowe i dach) oraz podwozie (ostoja wraz $z$ podłoga) odgrywa ważną rolę w zmniejszeniu masy całego pojazdu. Redukcję masy można osiągnać poprzez zmianę przekrojów poprzecznych głównych elementów konstrukcyjnych, zastosowanie innowacyjnych materiałów konstrukcyjnych lub połączenie zmiany przekrojów $\mathrm{z}$ zastosowaniem nowoczesnych materiałów $[1,6]$. Yao i współautorzy [10] podjęli próbę użycia lekkiego kompozytu do budowy elementów ramy wózka, zmniejszając masę tych części o około $30 \% \mathrm{w}$ stosunku do elementów wykonanych $\mathrm{z}$ tradycyjnych materiałów.

Kang SeungGu i współautorzy [4] proponują optymalizację topologii nadwozia wagonu piętrowego wysokich prędkości ze wskazaniem cześci, które można zastapić elementami z kompozytów wielowarstwowych. Dowiedziono, że nadwozie wykonane $\mathrm{z}$ elementów aluminiowych i kompozytowych może ważyć do $14 \%$ mniej, niż tradycyjna konstrukcja aluminiowa. Podobny wynik, około $14 \%$ redukcji masy, 
materials of some parts with composite ones. The use of composite materials, with consideration of their multifunctionality, i.e. possible combination of stiffness, good thermal and acoustic insulation, may contribute to reduction of the rail vehicle body mass by about $40 \%$ as compared to a conventional steel structure [8]. The connection of aluminum profiles with multilayered materials was also tested during the attempt aimed at mass reduction of the Maglev vehicle [5]. The results of the finite element analysis have shown that a hybrid body composed of extruded aluminum profiles and composite multi-layer plates is not only lighter than the one made only of aluminum profiles, but is distinguished by better structural strength.

Another element giving opportunity to reduction of the vehicle mass is the vehicle chassis. The authors [3] presented optimization of the internal floor of a rail vehicle with the use of multilayer plates. Such an approach enabled to reduce the mass by $60 \%$ with respect to usual structure of the floor. Wannberg et alii [9] proposed replacing the corrugated sheet used for floor and roof construction with a multi-layer plate. These measures allowed to reduce the mass by 600 $700 \mathrm{~kg}$.

The paper presents the chassis design of modern passenger coaches and proposes their optimization with a view to reduce their mass. Two solutions of the passenger coach of $\mathrm{Z} 1$ type with air conditioning are proposed: the compartment coach adapted for people with disabilities and open-saloon coach, with available carriage of bicycles. These coaches are intended for international traffic at a maximum speed of $200 \mathrm{~km} / \mathrm{h}$.

\section{Classical design of the passenger coach chassis}

The chassis of the passenger coach, being one of the load-bearing parts of the body, consists of a framework and a steel floor (Fig. 1). The framework is composed of three main parts [7]: the middle one and two end ones.

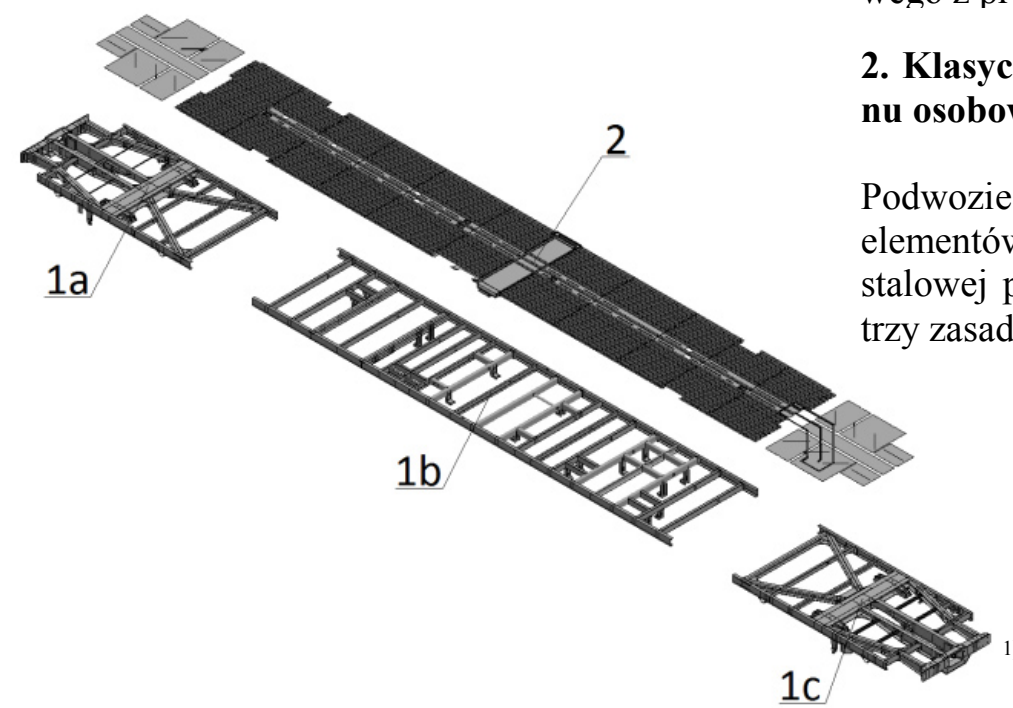

\section{Klasyczna budowa konstrukcji podwozia wago- nu osobowego}

Podwozie wagonu osobowego, które jest jednym z elementów nośnych pudła, składa się z ostoi oraz stalowej podłogi (rys. 1). Ostoję można podzielić na trzy zasadnicze części [7]: środkową i dwie skrajne.

Fig. 1. The passenger coach chassis 1 - framework, $1 \mathrm{a}-\mathrm{HBS}^{1}$, end part, $1 \mathrm{~b}-$ middle part, $1 \mathrm{c}$ - end part, 2 - steel floor

Rys. 1. Podwozie wagonu osobowego 1 - ostoja, 1a - część skrajna SHR ${ }^{1)}, 1$ b - część środkowa, 1c - część skrajna, 2 - podłoga stalowa otrzymali Jeong Gil Cho i współautorzy [2] podczas optymalizacji nadwozia K-EMU, zamieniając mate-

Zastosowanie materiałów kompozytowych z uwzględnieniem ich wielofunkcyjności, czyli możliwości połączenia na przykład sztywności, dobrej izolacji cieplnej oraz akustycznej, może zredukować [8]. Połączenie profili aluminiowych $\mathrm{z}$ materiałami podczas redukcji masy pojazdu Maglev [5].

Wyniki analizy elementów skończonych pokazały, że profili aluminiowych i kompozytowych plyt wielowarstwowych było nie tylko lżejsze, niż nadwozie wykonane $\mathrm{z}$ samych profili aluminiowych, ale i cechowało się lepszą wytrzymałością strukturalną.

Kolejnym elementem, dzięki któremu można zredukować mase pojazdu jest podwozie pojazdu. Autorzy zentowali optymalizacje podłogi wewnetrzlowarstwowych. Dzięki ich zastosowaniu możliwe było obniżenie masy o $60 \% \mathrm{w}$ stosunku do konwenzastapienie blachy falistej, stosowanej do budowy podłogi i dachu, płytą wielowarstwową. Dzięki temu zabiegowi obniżono masę o 600-700 kg.

współczesnych wagonów osobowych i zaproponowano możliwości ich optymalizacji w odniesieniu do konstrukcji podwozi wagonów osobowych typu Z1 z limatyzacją:

- przedziałowego przystosowanego do przewozu

- bezprzedziałowego przystosowanego do przewozu rowerów.

Te wagony są przeznaczone do ruchu międzynarodowego $\mathrm{z}$ prędkością maksymalną $200 \mathrm{~km} / \mathrm{h}$. 


\subsection{Middle part of the framework}

The middle part of the framework consists of two longitudinal girders made of rolled C-beams interconnected with cross girders of bended channel sections or box-shaped profiles (Fig. 2).
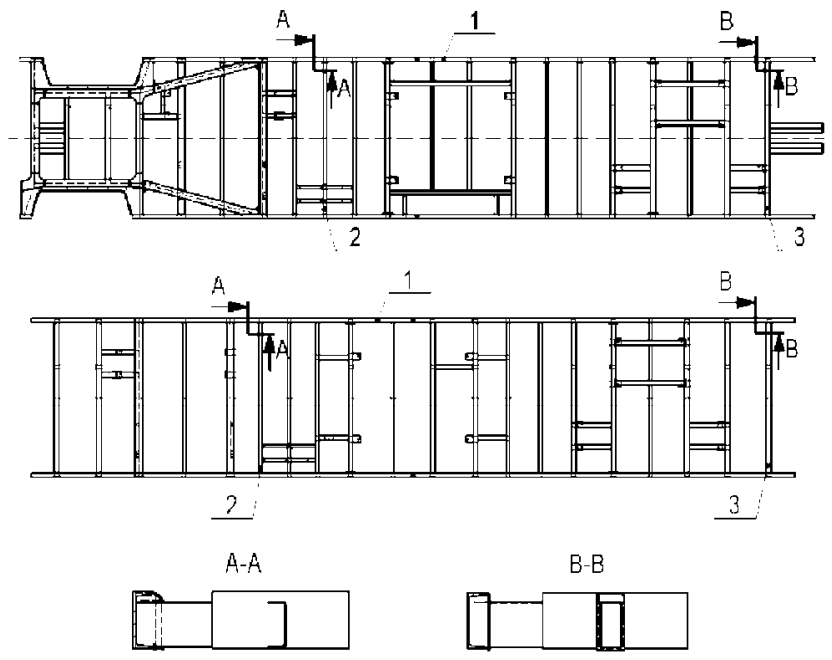

Fig. 2. Middle parts of the passenger coach frameworks, of the compartment and open-saloon coaches, respectively:

1 - longitudinal girder, 2 - cross girder (bended channel section), HBS - cross girder (box-shaped profile)

Rys. 2. Części środkowe ostoi wagonów osobowych odpowiednio przedziałowego i bezprzedziałowego

1 - ostojnica, 2 - poprzecznica (gięty ceownik), 3 - poprzecznica (profil zamknięty)

The middle parts of the compartment and open-saloon coaches are of different structures, that is a result of their particular adaptation to assembly of the devices necessary for proper functioning of the coach. These devices are of considerable size and weight inclusive, among others, e.g. air-conditioning and sanitary devices, accumulator batteries, or power supply equipment. In consequence, the arrangement of the cross-girders varies from one coach to another. Arrangement of side entrance doors significantly affects the framework design. In the case of a compartment coach one pair of entrance doors is located in middle part of the framework, which has a considerable impact on its design.

\subsection{End part of the framework}

The end part of the framework is composed of (Fig. 3):

- main pivot beam, being a box-shaped profile made of welded metal sheets;

- central longitudinal member made of rolled Cbeams;

- longitudinal girders (made in the form of a moulded profile) or the bracings behind the main pivot beam;

- longitudinal girders transforming into the bracings, in the form of I-beams made of welded metal sheets;

\subsection{Część środkowa ostoi}

Część środkowa ostoi składa się $\mathrm{z}$ dwóch ostojnic wykonanych z ceowników walcowanych połączonych ze sobą poprzecznicami $\mathrm{z}$ giętych ceowników lub z profili o przekroju zamkniętym (rys. 2).

Części środkowe ostoi wagonów, przedziałowego i bezprzedziałowego, posiadają różną budowę konstrukcyjną wynikającą z ich indywidualnego przystosowania do montażu urządzeń niezbędnych do prawidłowego funkcjonowania wagonu. Urządzenia te mają znaczące rozmiary i masy, a należą do nich między innymi urządzenia klimatyzacji wnętrza, urządzenia sanitarne, baterie akumulatorów oraz urządzenia zasilania w energię elektryczną. Skutkiem tego są różnice w układzie poprzecznic poszczególnych wagonów. Istotną rolę $\mathrm{w}$ konstrukcji ostoi ma także rozmieszczenie wejściowych drzwi bocznych. W przypadku wagonu przedziałowego jedna para drzwi wejściowych wypada w części środkowej ostoi, co ma znaczący wpływ na jej budowę.

\subsection{Część skrajna ostoi}

Część skrajna ostoi składa się z (rys. 3):

- belki skrętowej wykonanej, jako przekrój zamknięty spawany $\mathrm{z}$ blach

- belek grzbietowych wykonanych z ceowników walcowanych

- podłużnic (wykonanych w postaci kształtownika giętego) lub ukośnic za belką skrętową

- podłużnic przechodzących w ukośnice wykonanych jako dwuteowniki ze spawanych blach

- czołownicy wykonanej w postaci przekroju otwartego spawanego z blach

- ostojnic wykonanych z ceowników walcowanych

- poprzecznic.

Budowę konstrukcji części skrajnych ostoi wagonów: przedziałowego i bezprzedziałowego, determinuja mocowane na nich urządzenia pociagowo-zderzne oraz sposób połączenia pudła wagonu z wózkami. Elementy części skrajnych muszą być przystosowane do przenoszenia znacznych obciążeń powstających podczas eksploatacji wagonu, zarówno pionowych jak i wzdłużnych.

\subsection{Podłoga stalowa}

Podłoga stalowa (rys. 4) wykonana jest w częściach skrajnych z blach płaskich o grubości $3 \mathrm{~mm}$, natomiast $\mathrm{w}$ części środkowej stosowana jest blacha falista (ryflowana) o grubości $1 \mathrm{~mm}$. 

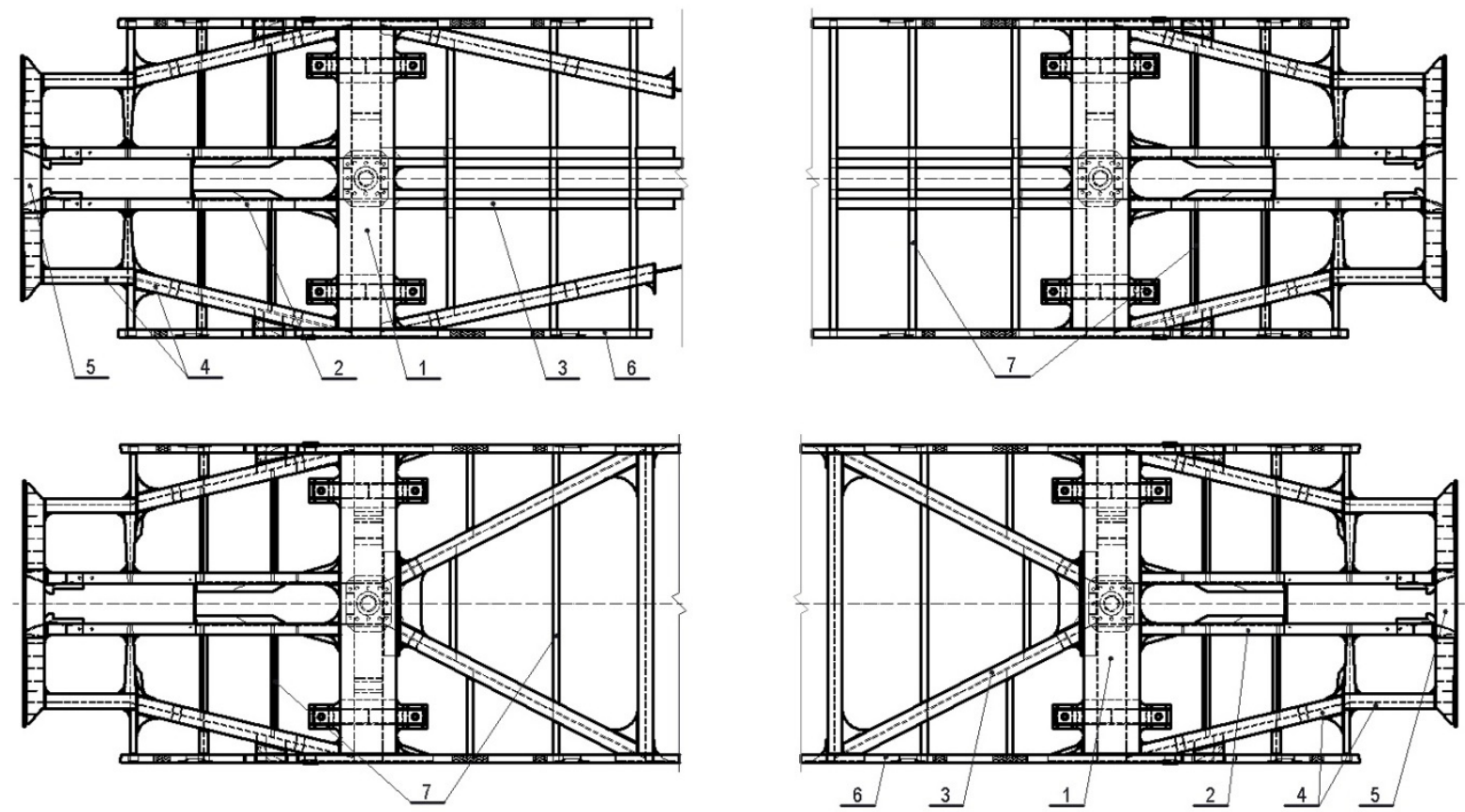

Fig. 3. End parts of the passenger coach frameworks, of the compartment and open-saloon coaches, respectively:

1 - main pivot beam, 2 - central longitudinal member, 3 - longitudinal girder or the bracing behind the main pivot beam, 4 longitudinal girder with bracing, 5 - buffer beam,

Rys. 3. Części skrajne ostoi wagonów osobowych odpowiednio przedziałowego i bezprzedziałowego

1 - belka skrętowa, 2 - belka grzbietowa, 3 - podłużnica lub ukośnica za belką skrętową, 4 - podłużnica z ukośnica, 5 czołownica, 6 - ostojnica, 7 - poprzecznice
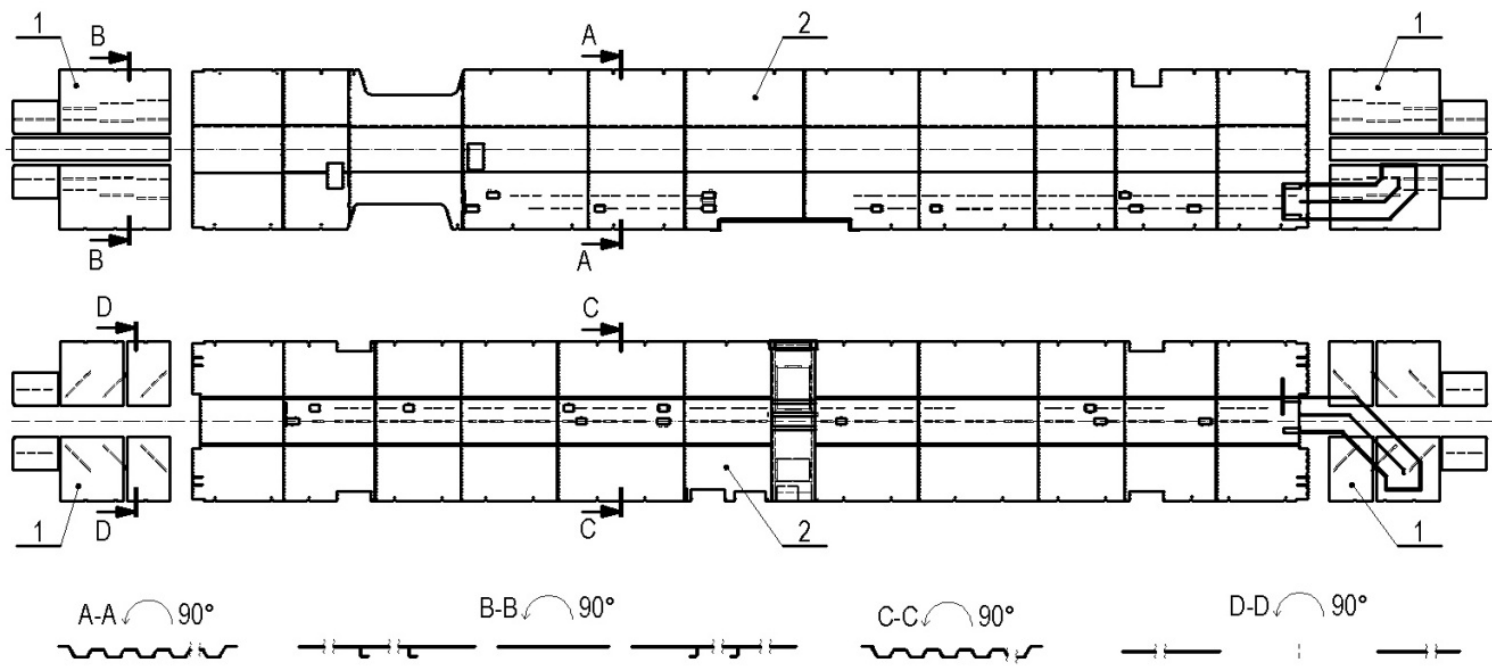

Fig. 4. Steel floors of compartment and open-saloon coaches, respectively:

1 - flat sheet, 2 - corrugated metal sheet

Rys. 4. Podłogi stalowe wagonów osobowych, odpowiednio przedziałowego i bezprzedziałowego

1 - blacha płaska, 2 - blacha falista (ryflowana)

- buffer beam in the form of an open profile made of welded metal sheets;

- longitudinal girders made of rolled C-beams;

- cross girders.

The structure of the end parts of the frameworks of compartment and open-saloon coaches is imposed by the coupling-buffing gears attached to them and the way of coupling the coach body to the bogies. The elements of the end parts must be capable of carrying high vertical and longitudinal loads arising during the coach operation.

\section{Udział masowy poszczególnych części podwozia}

Masa podwozia stanowi ponad $50 \%$ masy pudła wagonu. Na całkowitą mase podwozia wagonu osobowego składają się masy takich elementów, jak części skrajne, część środkowa oraz podłoga stalowa. W tabeli 1 zestawiono masy poszczególnych części podwozi omawianych wagonów. 


\subsection{Steel floor}

End parts of the steel floor (Fig. 4) is made of flat sheets $3 \mathrm{~mm}$ thick, while the middle part is made of corrugated sheet $1 \mathrm{~mm}$ thick.

\section{Mass fraction of particular parts of the chassis}

Chassis weight exceeds $50 \%$ of the coach body weight. The total mass of the coach's chassis comprises the masses of the end parts, the middle section and the steel floor. Table 1 specifies the masses of particular chassis parts of the considered coaches.

Table 1. Specification of the masses of particular chassis parts

Tablica 1 Zestawienie mas poszczególnych elementów podwozia wagonów osobowych

\begin{tabular}{|c|c|c|c|}
\hline $\begin{array}{l}\text { Lp. } \\
\text { Item }\end{array}$ & $\begin{array}{c}\text { Element } \\
\text { podwozia wagonu } \\
\text { osobowego } \\
\text { Part of the } \\
\text { passenger coach } \\
\text { chassis }\end{array}$ & $\begin{array}{c}\text { Masa } \\
\text { podwozia } \\
\text { wagonu } \\
\text { osobowego } \\
\text { przedzialo- } \\
\text { wego [kg] } \\
\text { Mass of the } \\
\text { compartment } \\
\text { passenger } \\
\text { coach chassis } \\
{[\text { kg] }}\end{array}$ & $\begin{array}{c}\text { Masa } \\
\text { podwozia } \\
\text { wagonu } \\
\text { osobowego } \\
\text { bezprzedziało- } \\
\text { wego [kg] } \\
\text { Mass of the } \\
\text { open saloon } \\
\text { passenger } \\
\text { coach chassis } \\
{[\text { kg] }}\end{array}$ \\
\hline 1. & $\begin{array}{c}\text { Część skrajna } \\
\text { ostoi } \\
\text { framework end } \\
\text { part } \\
\end{array}$ & 1794.79 & 1857.52 \\
\hline a) & $\begin{array}{l}\text { Belka skrętowa } \\
\text { Main pivot beam }\end{array}$ & 413.33 & 450.98 \\
\hline b) & $\begin{array}{c}\text { Belki grzbietowe } \\
\text { central } \\
\text { longitudinal beam }\end{array}$ & 219.17 & 218.83 \\
\hline c) & $\begin{array}{c}\text { Podtużnice lub } \\
\text { ukośnice za belka } \\
\text { skrętowa } \\
\text { Longitudinal and } \\
\text { diagonal girders } \\
\text { behind the main } \\
\text { pivot beam }\end{array}$ & 232.13 & 153.54 \\
\hline d) & $\begin{array}{c}\text { Podtużnice z } \\
\text { ukośnicami } \\
\text { Longitudinal and } \\
\text { diagonal girders }\end{array}$ & 199.48 & 199.48 \\
\hline e) & $\begin{array}{l}\text { Czolownica } \\
\text { Frame end }\end{array}$ & 167.16 & 167.16 \\
\hline f) & $\begin{array}{c}\text { Ostojnice } \\
\text { Longitudinal } \\
\text { girders } \\
\end{array}$ & 230.08 & 241.60 \\
\hline g) & $\begin{array}{l}\text { Poprzecznice } \\
\text { Cross girders }\end{array}$ & 112.59 & 169.35 \\
\hline h) & $\begin{array}{c}\text { Pozostate } \\
\text { Others }\end{array}$ & 220.85 & 256.58 \\
\hline 2. & $\begin{array}{c}\text { Część środkowa } \\
\text { ostoi } \\
\text { framework } \\
\text { middle part }\end{array}$ & 2058.56 & 1671.72 \\
\hline a) & $\begin{array}{c}\text { Ostojnice } \\
\text { Longitudinal } \\
\text { girders }\end{array}$ & 645.03 & 688.54 \\
\hline b) & $\begin{array}{l}\text { Poprzecznice } \\
\text { Cross girders }\end{array}$ & 742.43 & 763.35 \\
\hline c) & $\begin{array}{c}\text { Pozostate } \\
\text { Others }\end{array}$ & 671.10 & 219.83 \\
\hline
\end{tabular}

Table 1 cont.

\begin{tabular}{|c|c|c|c|}
\hline 3. & $\begin{array}{l}\text { Część skrajna ostoi } \\
\text { Framework end part }\end{array}$ & 1610.91 & 1857.19 \\
\hline a) & $\begin{array}{c}\text { Belka skrętowa } \\
\text { Main pivot beam }\end{array}$ & 413.33 & 450.01 \\
\hline b) & $\begin{array}{c}\text { Belki grzbietowe } \\
\text { central longitudinal beam }\end{array}$ & 219.17 & 218.58 \\
\hline c) & $\begin{array}{l}\text { Podhużnice lub ukośnice za } \\
\text { belka skrętowa } \\
\text { Longitudinal and diagonal } \\
\text { girders behind the main } \\
\text { pivot beam }\end{array}$ & 47.32 & 154.05 \\
\hline d) & $\begin{array}{l}\text { Podhużnice z ukośnicami } \\
\text { Longitudinal and diagonal } \\
\text { girders }\end{array}$ & 199.48 & 199.48 \\
\hline e) & $\begin{array}{l}\text { Czolownica } \\
\text { Frame end }\end{array}$ & 167.16 & 167.16 \\
\hline f) & $\begin{array}{c}\text { Ostojnice } \\
\text { Longitudinal girders }\end{array}$ & 231.5 & 241.60 \\
\hline g) & $\begin{array}{l}\text { Poprzecznice } \\
\text { Cross girders }\end{array}$ & 117.73 & 169.35 \\
\hline h) & $\begin{array}{c}\text { Pozostate } \\
\text { Others }\end{array}$ & 215.22 & 256.96 \\
\hline 4. & $\begin{array}{c}\text { Podłoga stalowa } \\
\text { Steel floor } \\
\end{array}$ & 723.43 & 713.60 \\
\hline a) & $\begin{array}{l}\text { Część wykonana z blachy } \\
\text { ptaskiej } \\
\text { The part made of flat sheet }\end{array}$ & 220.32 & 163.70 \\
\hline b) & $\begin{array}{c}\text { Częśc wykonana z blachy } \\
\text { falistej } \\
\text { The part made of } \\
\text { corrugated sheet }\end{array}$ & 503.11 & 549.9 \\
\hline & SUMA TOTAL & 6187.69 & 6100.03 \\
\hline
\end{tabular}

$\mathrm{Na}$ wykresach (rys. 5, 6) zaprezentowano rozkłady mas poszczególnych elementów podwozi wagonów osobowych (przedziałowego i bezprzedziałowego). Wykresy pokazują, że części ostoi stanowią około 88 $\%$ masy całego podwozia, a podłoga jedynie $12 \%$. Masy elementów ostoi rozkładają się równomiernie i stanowią około $30 \%$ masy całego podwozia.

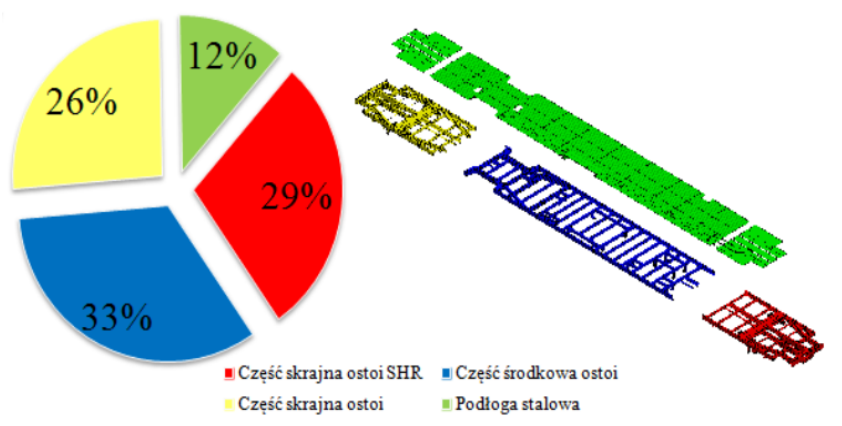

Fig. 5. Mass distribution of the chassis parts of a compartment passenger coach

Rys. 5. Rozkład masy elementów podwozia wagonu osobowego przedziałowego 
The graphs above (Figs 5, 6) show the mass distributions of particular chassis components of compartment and open-saloon passenger coaches. The graphs indicate that the framework parts account for about $88 \%$ of the entire chassis mass, while the floor mass amounts only to $12 \%$. The masses of the framework components are uniformly distributed and constitute about $30 \%$ of the whole chassis mass.

The graph below (Fig. 7) presents the percentage mass fractions of the framework end part components at the screw brake side of the compartment and open-saloon passenger coaches. The masses of the main pivot beams of the considered coaches predominate, representing $23-24 \%$ of total mass of the SBS framework end part.

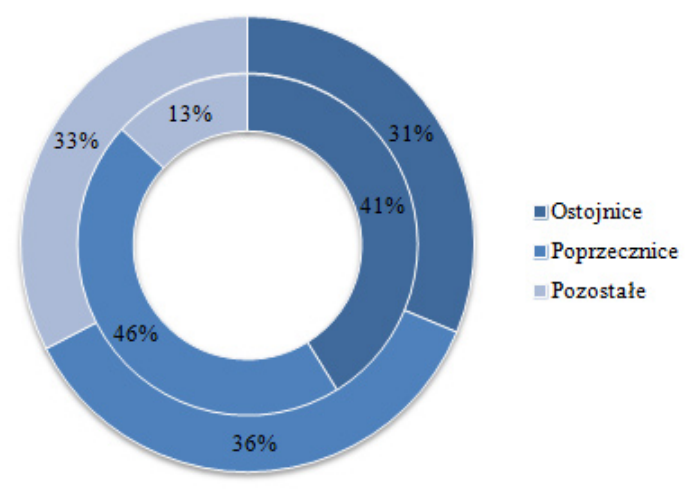

Fig 8. Mass distribution of the framework middle part outer ring - the compartment coach, inner ring - the open-saloon coach

Rys. 8. Rozkład masy elementów części środkowej ostoi (pierścień zewnętrzny - wagon przedziałowy, pierścień wewnętrzny - wagon bezprzedziałowy)

The graph (Fig. 8) specifies the percentage mass fractions of the framework middle part components of the compartment and open-saloon passenger coaches. The mass distribution of the basic components, i.e. longitudinal and cross girders, is uniform. In case of the compartment coach the share of the "other" components is higher, taking about $33 \%$ of the total mass of the middle framework part. This is due to the side access doors that are located in this part of the coach. The framework cross section is narrowed in this location and strengthened with additional components (Fig. 2) resulting in the mass increase.

The graph below (Fig. 9) presents the percentage mass fractions of the framework end part components at the screw brake side of the compartment and open-saloon passenger coaches. The masses of the main pivot beams of the considered coaches predominate, representing $23-24 \%$ of total mass of the SBS framework end part.

The largest mass fraction of the coach steel floor, amounting to $70-77 \%$, is represented by the corrugated sheet floor of the middle framework part (Fig. 10).

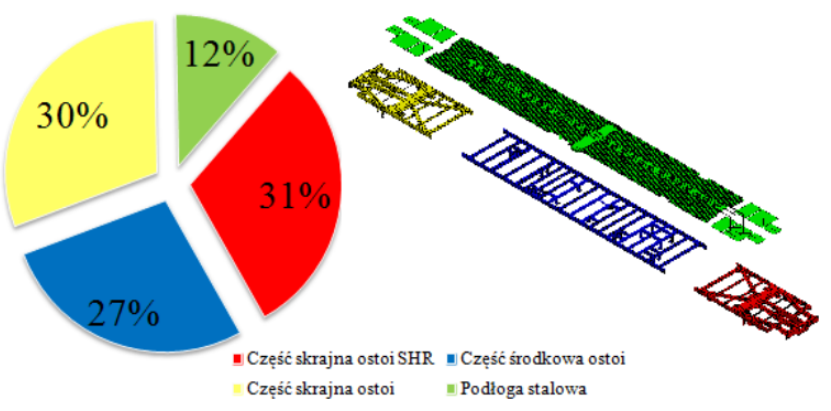

Fig 6. Mass distribution of the chassis parts of an open-saloon passenger coach

Rys. 6. Rozkład masy elementów podwozia wagonu osobowego bezprzedziałowego

$\mathrm{Na}$ wykresie poniżej (rys. 7) zestawiono procentowe udziały mas elementów tworzących części skrajne ostoi po stronie hamulca ręcznego wagonów (przedziałowego i bezprzedziałowego). Największy udział stanowią belki skrętowe omawianych wagonów, to jest 23-24 \% całkowitej masy części skrajnej SHR.

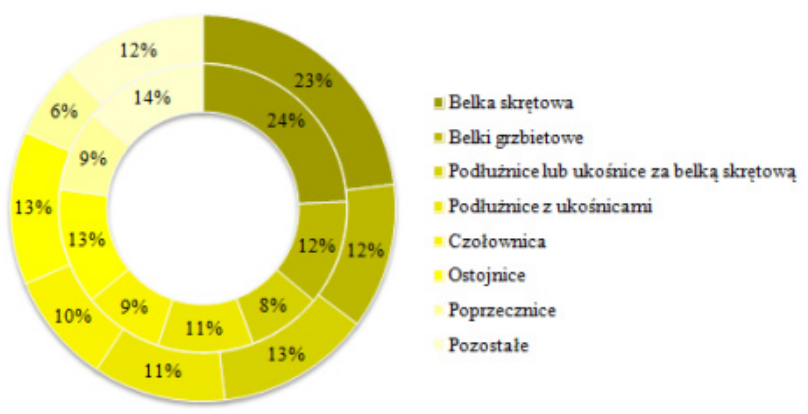

Fig 7. Mass distribution of the SBS framework end part outer ring - the compartment coach, inner ring - the open-saloon coach

Rys. 7. Rozkład masy elementów części skrajnej SHR ostoi (pierścień zewnętrzny - wagon przedziałowy, pierścień wewnętrzny - wagon bezprzedziałowy)

Na wykresie (rys. 8) zestawiono procentowe udziały mas elementów tworzących części środkowe ostoi wagonów (przedziałowego i bezprzedziałowego). Rozkład masy zasadniczych elementów (ostojnic, poprzecznic) jest równomierny. W wagonie przedziałowym uwidocznia się znaczy udział elementów "pozostałych", czyli ok. 33 \% masy całkowitej części środkowej ostoi. Spowodowane jest to usytuowaniem wejściowych drzwi bocznych, które znajdują się w tej części wagonu. W miejscu drzwi następuje przewężenie ostoi (w przekroju poprzecznym), które zostało wzmocnione dodatkowymi elementami ( rys. 2) powodując wzrost masy.

Na wykresie poniżej (rys. 9) zestawiono procentowe udziały mas elementów tworzących części skrajne ostoi wagonów (przedziałowego i bezprzedziałowego). Analogicznie do części skrajnych SHR największy udział stanowią belki skrętowe omawianych wagonów, to jest 24-26\% całkowitej masy części skrajnej. 


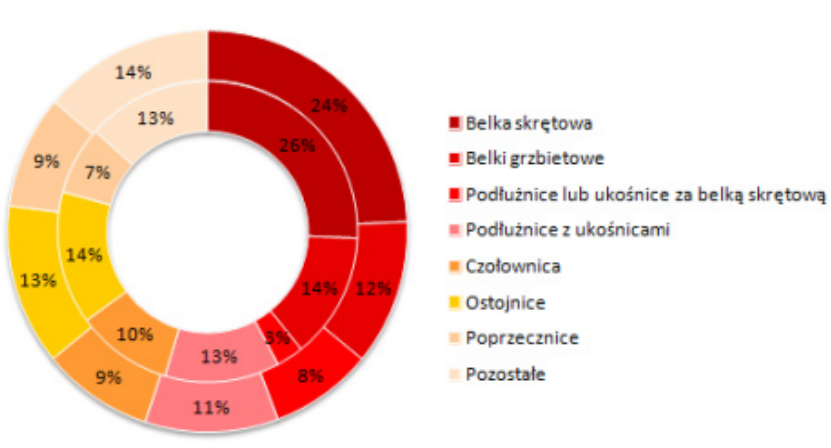

Fig 9. Mass distribution of the framework end part outer ring - the compartment coach, inner ring - the open-saloon coach

Rys. 9. Rozkład masy elementów części skrajnej ostoi (pierścień zewnętrzny - wagon przedziałowy, pierścień wewnętrzny - wagon bezprzedziałowy)

\section{Development directions of the passenger coach chassis design}

According to the charts presented above the main structural components affecting the mass of a passenger coach chassis are:

- main pivot beams,

- longitudinal girders,

- cross girders,

- steel floor made of corrugated sheet.

The first optimization stage should advisably consist in modification of the cross-sections of some of the main pivot beams, longitudinal and cross girders, in order to reduce the coach chassis mass. Afterwards, replacement of the conventional materials used to build the above mentioned parts with modern construction materials should be considered. This might enable to assess which optimization direction gives better mass reduction. Subsequently, possible substitution of the steel floor for the one made of multilayer composite materials should be considered, that should allow to estimate possible reduction of the mass of this part of the coach chassis.

Introduction of the above mentioned changes requires undoubtedly appropriate analyzes in order to confirm sufficient strength of the new chassis design.

\section{Summary}

Based on the literature studies, optimization of the rail vehicle chassis structure aimed at reduction of their mass can be carried out by the following methods:

- modification of cross-sections of basic structural components of the chassis;

- replacing conventional construction materials with the modern materials, inclusive of high-strength and composite ones;

- simultaneous modifications of the cross-section and application of modern construction materials.

Juxtaposition of two constructions of the passenger coach chassis - the compartment and open saloon ones
W podłodze stalowej wagonu największy udział masy stanowi podłoga $\mathrm{z}$ blachy falistej $\mathrm{w}$ części środkowej ostoi $70-77 \%$ (ryc. 10).

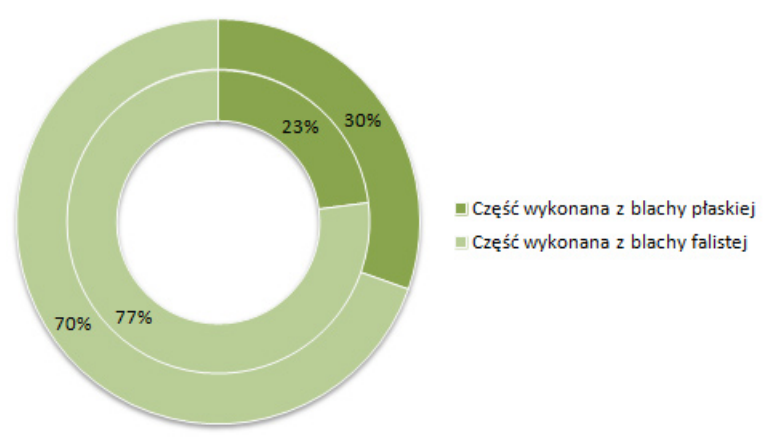

Fig 10. Mass distribution of the steel floor outer ring - the compartment coach, inner ring - the open-saloon coach

Ryc. 10. Rozkład masy elementów części podłogi stalowej (pierścień zewnętrzny - wagon przedziałowy, pierścień wewnętrzny - wagon bezprzedziałowy)

\section{Kierunki rozwoju budowy konstrukcji podwozi wagonów osobowych}

Głównymi elementami konstrukcyjnymi, które mają wpływ na masę podwozia wagonu osobowego, jak wynika z wykresów powyżej, są:

- belki skrętowe

- ostojnice

- poprzecznice

- podłoga stalowa z blachy falistej.

W pierwszym etapie optymalizacji wskazane jest zmodyfikowanie przekrojów porzecznych części belek skrętowych, ostojnic i poprzecznic w celu zredukowania masy podwozia wagonu. W następnej kolejności należałoby rozważyć zastapienie konwencjonalnych materiałów wykorzystywanych do budowy omawianych części nowoczesnymi materiałami konstrukcyjnymi, co pozwoli ocenić, który kierunek optymalizacji daje lepsze rezultaty redukcji masy. W dalszej kolejności należy rozważyć możliwość zastąpienia podłogi stalowej podłogą wykonaną z wielowarstwowych materiałów kompozytowych, co pozwoli na ocenę możliwości redukcji masy tej części podwozia wagonowego.

Niewątpliwie wprowadzenie powyższych zmian wymaga przeprowadzenia stosownych analiz potwierdzających wystarczającą wytrzymałość konstrukcji nowego podwozia.

\section{Podsumowanie}

$\mathrm{Na}$ podstawie badań literatury optymalizację konstrukcji podwozi pojazdów szynowych w stosunku do ich masy można przeprowadzić metodami, takimi jak:

- modyfikacja przekrojów poprzecznych zasadniczych elementów konstrukcyjnych podwozia

- zastapienie konwencjonalnych materiałów konstrukcyjnych nowoczesnymi, w tym wysokowytrzymałymi oraz kompozytowymi 
- allows to distinguish characteristic common components of similar structure in both coach types. These are two end parts, the middle part and a steel floor.

Analysis of the mass distribution of particular components of the passenger coach chassis, enables to point out the parts significantly affecting the mass of the entire structure to be optimized. These include main pivot beams, longitudinal and cross girders and steel floor made of corrugated metal sheet.

\section{Bibliography / Bibliografia}

[1] Cho J. G., Koo J. S., Jung H. S., A lightweight design approach for an EMU carbody using a material selection method and size optimization. Journal of Mechanical Science and Technology, Vol. 30, Issue 2, 2016, p. 673-681.

[2] Cho J. G., Koo J. S., Jung H. S., Study on Weight Reduction of Urban Transit Carbody Based on Material Changes and Structural Optimization. Transactions of the Korean Society of Mechanical Engineers A, Vol. 37, Issue 9, 2013, p. 1099-11078.

[3] Hudson C. W., Carruthers J. J., Robinson A. M., Multiple objective optimisation of composite sandwich structures for rail vehicle floor panels. Composite Structures, 92, 2010, p. 2077-2082.

[4] Kang, S. G., Shin K. B., Ko T. H., You W. H., Lightweight Design of Car Bodies for Double Deck HighSpeed Trains. Journal of the Korean Society of Manufacturing Technology Engineers, Vol. 24, 2015, p. 177185.

[5] Kang, S. G., Shin K. B., Park K. J. i in., Study on the Weight-Reduction Design of High-Speed Maglev Carbodymade of Aluminum Extrusion and Sandwich Composite Roof. Transactions of the Korean Society of Mechanical Engineers A 38(10), 2014, p. 1093-1100.

[6] Kuczek T., Szachniewicz B., Topology optimisation of railcar composite structure. International Journal of Heavy Vehicle Systems (IJHVS), Vol. 22, No. 4, 2015, p. 375-385.

[7] Kuligowski P., Wybrane zagadnienia zwiqzane z unifikacja konstrukcji ostoi wagonu pasażerskiego typu Z. Pojazdy Szynowe, Vol. 3, 2005, p. 41-47.

[8] Wennberg D., Stichel S., Multi-functional design of a composite high-speed train body structure. Structural and Multidisciplinary Optimization, 50, 2014, p. 475-488.

[9] Wennberg D., Stichel S., Wennhage P., Substitution of corrugated sheets in a railway vehicle's body structure by a multiple-requirement based selection process. Proceedings of the Institution of Mechanical Engineers Part F: Journal of Rail and Rapid Transit, Vol. 228, Issue 2, 2014, p. 143-157.

[10] Yao K., Yang Y., Li H. i in., Material characterization of a multi-cavity composite structure for the bogie frame of urban maglev train. Composites Part B: Engineering, Vol. 99, 2016, p. 277-287. 